\title{
Article
}

\section{Prescribing for patients at the end of life}

\author{
Ritchie, Georgina Louise
}

Available at http://clok.uclan.ac.uk/20711/

Ritchie, Georgina Louise (2017) Prescribing for patients at the end of life. Nurse Prescribing, 15 (11). pp. 533-535. ISSN 1479-9189

It is advisable to refer to the publisher's version if you intend to cite from the work.

For more information about UCLan's research in this area go to

http://www.uclan.ac.uk/researchgroups/ and search for <name of research Group>.

For information about Research generally at UCLan please go to http://www.uclan.ac.uk/research/

All outputs in CLoK are protected by Intellectual Property Rights law, including Copyright law. Copyright, IPR and Moral Rights for the works on this site are retained by the individual authors and/or other copyright owners. Terms and conditions for use of this material are defined in the policies page.

\section{CLoK}




\section{Question 1}

(i) $65000000 / 500=130,000$ people

(ii) 1,205 rounded up

\section{Question 2}

(i) 0.89 rounded up

(ii) venous

(iii) $78,00026,00026,000$

\section{Question 3}

Bacteria will always be present in leg ulcers and routine prescribing of antibiotics does NOT improve healing. Culture swabs and antibiotics are only indicated if there is evidence of clinical infection such as inflammation/redness/cellulitis/increased pain/ purulent exudate/rapid deterioration of ulcer or pyrexia.

John is a 45 year-old joiner, has had a venous leg ulcer for approximately 9 weeks, he frequently doesn't comply with his treatment plan and has developed cellulitis. In line with NICE (2015) guidance, he is prescribed Flucloxacillin $500 \mathrm{mg}$ four times daily for 7 days.

(i) $\quad 7 \times 4=28$ tablets

(ii) $7 \times 500 \mathrm{mg}=3500 \mathrm{mg}=3.5 \mathrm{~g}$ grams.

(iii) $500 \mathrm{mg}$ twice per day $=1$ gram per day $\times 7$ days $=7$ grams in total.

(iv) Flucloxacillin $£ 14.00$

Table 2

\begin{tabular}{|c|c|c|c|}
\hline Drug & Dose & $\begin{array}{l}\text { Duration of } \\
\text { treatment }\end{array}$ & Cost \\
\hline Flucloxacillin & $\begin{array}{l}500 \text { mg four } \\
\text { times daily }\end{array}$ & 7 days & $500 \mathrm{mg}$ capsule $f 7.50 \times 28$ capsules \\
\hline Clarithromycin & $\begin{array}{l}500 \mathrm{mg} \text { twice } \\
\text { daily }\end{array}$ & 7 days & $500 \mathrm{mg}$ tablet $\mathrm{f} 21.50 \times 14$ tablets \\
\hline
\end{tabular}

\section{Question 4}

(i) $\quad 30$ g per day $\times 7$ days $=210$ grams per week

$210 \mathrm{~g}$ per week $\times 8$ weeks $=1680$ grams in total needed

Therefore $4 \times 500$ gram tubs at a cost of $6 \times £ 6.32=£ 25.28$

(ii) $\quad 30 \mathrm{~g}$ of diprobase per day $=210 \mathrm{~g}+100 \mathrm{mls}$ of eucerin over 7 days total $310 \mathrm{grams}$.

\section{Question 5}

$9 \times 64 \mathrm{mg}=576 \mathrm{mg}$ of codeine and $9 \times 4000 \mathrm{mg}$ of paracetamol $=36000.576 / 36000 \mathrm{in} \mathrm{mg}$ or 36 grams. Advise to buy over the counter. 


\section{$\underline{\text { Question } 6}$}

Minimum review of once per year, Arthur will live for 8 years and two months so a minimum of 8 more appointments will be needed. 